Original Research

\title{
Effects of Handgrip Relaxation on Decreasing Blood Pressure in Patients with Hypertension
}

\author{
Moomina Siauta $^{1}$, Selpina Embuai ${ }^{1}$ and Hani Tuasikal $^{2}$ \\ ${ }^{1}$ Universitas Kristen Indonesia Maluku, Indonesia \\ ${ }^{2}$ Akper Rumkit Tk III Dr. J. A. Latumeten Ambon, Indonesia
}

\section{ABSTRACT}

Introduction: Hypertension is a leading cause of death if it is not properly treated. Handgrip relaxation is an intervention that can be used to reduce the blood pressure in patients with hypertension. The purpose of this study was to determine the effects of handgrip relaxation on decreasing blood pressure in patients with hypertension.

Methods: This study used a pre-test-post-test design with a control group and it was conducted at RSUD Dr. M. Haulussy, Ambon. The sample consisted of 14 patients aged 18 to 75 who suffered from hypertension type 1 and 2 . The sampling method was consecutive sampling and the patients were divided into the intervention $(n=7)$ and control group $(n=7)$. Handgrip relaxation was administered to the patients in the intervention group. The data was analyzed using a One-Way ANOVA test.

Results: The results showed a decrease in the systolic and diastolic blood pressures on the 3rd day with the highest mean value found in the intervention group and the control group had a significance value of 0.003 $(\mathrm{p}<0.05)$ and $0.014(\mathrm{p}<0.05)$

Conclusion: Handgrip relaxation had an effect on the decrease of systolic and diastolic blood pressures in patients with hypertension. Handgrip relaxation that was given for fifteen minutes over three days can be recommended as a nursing intervention to decrease the blood pressure of hypertensive patients.
\end{abstract}

\section{ARTICLE HISTORY}

Received: Dec 26, 2019

Accepted: Dec 31, 2019

\section{KEYWORDS}

handgrip; relaxation; blood pressure; hypertension

\section{CONTACT}

Moomina Siauta

$\triangle$ moominasiauta@gmail.com

$\supseteqq$ Universitas Kristen Indonesia

Maluku, Indonesia

Cite this as: Siauta, M., Embuai, S., \& Tuasikal, H. (2019). Effects of Handgrip Relaxation on Decreasing Blood Pressure in Patients with Hypertension.Jurnal Ners, 14(3si), 117-120. doi:http://dx.doi.org/10.20473/jn.v14i3(si).17036

\section{INTRODUCTION}

Hypertension or high blood pressure is a common condition which occurs in almost one-third of the population in the world. Hypertension has been one of the leading causes of mortality (Klabunde, 2015). The World Health Organization (WHO) in 2012 reported that the number of hypertension cases worldwide reached 839 million. It is estimated that the number will increase to approximately 1.15 billion in 2025 or $29 \%$ of the total world population. The cases of hypertension are mostly found in women by as much as $30 \%$ and in men by as much as $29 \%$. This number will especially increase by $80 \%$ in developing countries (Triyanto, 2015; Triyanto, Iskandar, \& Saryono, 2012).
The prevalence of hypertension in people aged 18 years old and over in Indonesia in 2013 is $9.4 \%$ and $25.8 \%$ based on the diagnosis of health workers and blood pressure measurement respectively. The highest prevalence of hypertension based on the diagnosis of health personnel was found in Bangka Belitung by as much as $30.9 \%$. The lowest was found in Papua province by as much as $16.8 \%$. Furthermore, Sulawesi and Kalimantan are reported to have a sufficient prevalence of hypertension. Hypertension is a risk factor for cardiovascular disease and it is the third most common cause of death after stroke and tuberculosis. The number reached $6.8 \%$ out of the death causes for all ages in Indonesia (Kementerian Kesehatan Republik Indonesia, 2014). 
Table 1. Data Analysis Using One-Way ANOVA

\begin{tabular}{lcccccc}
\hline Variable & \multicolumn{2}{c}{ Control Group } & \multicolumn{2}{c}{ Intervention Group } & Chi Square & Significance \\
& Mean & SD & Mean & SD & & \\
\hline Systolic Pressure & & & & & & \\
$\quad$ Day 1 & 0.000 & 0.000 & 1.429 & 3.631 & 4.231 & 0.238 \\
$\quad$ Day 2 & 0.000 & 0.000 & 5.714 & 5.136 & 20.091 & 0.000 \\
$\quad$ Day 3 & 0.000 & 0.000 & 5.000 & 5.189 & 13.657 & 0.003 \\
Diastolic Pressure & & & & & & \\
$\quad$ Day 1 & 1.429 & 5.714 & 5.345 & 6.462 & 7.009 & 0.072 \\
Day 2 & 0.000 & 0.000 & 8.571 & 6.630 & 24.805 & 0.000 \\
Day 3 & -3.571 & 11.507 & 7.143 & 6.113 & 10.560 & 0.014 \\
\hline
\end{tabular}

The prevalence of hypertension in RSUD Dr. M. Haulussy Ambon is quite high. There were 635 cases of hypertension reported in the last three years. In 2013 , the prevalence was $30.86 \%$. There was an increase in the percentage of hypertensive patients by $36.86 \%$ in 2014 and a decrease with a percentage of $32.27 \%$ in 2015 (Rekamedik RSUD Dr. M. Haulussy Ambon, 2016). Interviews with the nurses in both the male and female patient medical wards, and on the male and female patients' surgical wards revealed that deep breathing relaxation was an independent nursing intervention given to patients in the early stages of treatment. However, this intervention is not routinely carried out as it is only taught at the beginning of the therapy administration. Next, pharmacological therapy is then used to reduce the blood pressure and headaches that the patients have.

Increased blood pressure in the arteries can occur in multiple stages. At first, the heart will contract more strongly so then there will be more blood flow every second. As a result, large arteries will lose their flexibility and become stiff so then they cannot expand in the process of blood pumping through the arteries. The blood will be forced to pass through narrow vessels and this causes increased pressure. Such a condition happens to some elderly people, in which the artery walls are stiff due to arteriosclerosis. Increasing the circulatory fluid can cause increased blood pressure. This happens if there are abnormalities in kidney function, as the kidneys are unable to remove a certain amount of blood and water from the body. The volume of blood in the body increases and so does the blood pressure. In contrast, if the heart relaxes then the arteries will experience widening, causing lots of fluid to get out of circulation. Thus, the blood pressure will decrease. In this context, the kidneys and the autonomic nervous system (a part of the nervous system that regulates various bodily functions automatically) are responsible for adapting to these factors (Mortimer \& McKune, 2011).

An appropriate management method for hypertension is needed to reduce the impact of pharmacological therapy and non-pharmacological therapy. One of the alternatives of nonpharmacological treatments which can be implemented is the relaxation technique. Relaxation is one of the self-management techniques based on the working of the sympathetic and parasympathetic nervous system (Kaplan, 2002) (Ferguson, 1982).
This study aimed to investigate the effects of handgrip relaxation on reducing blood pressure in patients with hypertension in Dr. RSUD. M. Haulussy Ambon.

\section{MATERIALS AND METHODS}

This study employed a pre-post-test quasiexperimental research design. The sample consisted of 50 patients with hypertension in the medical polyclinic of RSUD Dr. M. Haulussy Ambon who were assigned to the intervention group $(n=25)$ and the control group $(n=25)$. Consecutive sampling was used to recruit the samples. The intervention of handgrip relaxation was given to the patients in the intervention group. The data was collected through blood pressure measurements before and after the intervention. Handgrip relaxation is an easy way to manage feelings and emotions and to develop emotional intelligence. Along the fingers, there are energy channels or meridians that are connected to various organs and emotions. Reflection points on the hands provide spontaneous stimulation (reflex) when an individual grasps his fingers (Liana, 2008). At first, the patients were tested for their initial blood pressure and then they were given time to rest for 5 10 minutes. After that, the patients in the intervention group were given handgrip relaxation for 15 minutes. A short break was also given before the final blood pressure measurement was conducted. An observation sheet for the blood pressure measurement was used in this study. The collected data was then analyzed using a One-Way ANOVA test (Nursalam, 2016).

\section{RESULTS}

Table 1 shows the highest decrease in systolic blood pressure and diastolic blood pressure on the third day in the intervention group with a significance value of $0.003(<0.05)$ and $0.014(<0.05)$ respectively. The result of the ANOVA test showed that handgrip relaxation was considered to be the most effective intervention at reducing blood pressure on the third day. The mean difference test showed a significant decrease in diastolic pressure between the pre and post-tests, indicating that the intervention could effectively decrease blood pressure.

\section{DISCUSSION}

The respondents in this study were patients with hypertension who visited the medical polyclinic at 
RSUD Dr. M. Haulussy Ambon. The patients were aged from 41 to 70 years, indicating that they were middle adults. Most of the respondents (28.6\%) were in the age range of 41 - 50. This study is in line with the theory that blood pressure in adults increases with age. In the elderly, systolic blood pressure increases along with decrease in blood vessel elasticity (Carlson et al., 2016).

In this study, $53.6 \%$ of the respondents were women. This is different from a theory which states that the incidence of hypertension is higher in men than in women up to the age of 55 years. The risk of hypertension is almost the same between the age of $55-74$. Women are at a higher risk after the age of 74. Kaplan (2002) stated that women have a better tolerance than men to hypertension (Muhadi, 2016). Clinically, there is no significant difference in blood pressure between men and women. After puberty, men tend to have higher blood pressure and women after menopause tend to have a higher blood pressure than men at the same age (Kozier, B., Erb, G., 1997).

The majority of respondents (75\%) had a family history of hypertension. Hypertension is caused by polygenics and many other factors in which some genes may interact with the environment, causing blood pressure to increase in the future (Pinandita, Purwanti, \& Utoyo, 2012). Genetic predisposition in families is more acceptable in hypertension. This may be related to increased intracellular sodium and a decreased ratio of potassium and sodium that often occurs in black people.

In this study, $53.6 \%$ of respondents had a history of smoking. In smokers, $\mathrm{CO}$ and nicotine in cigarettes can damage the endothelial cells and cause the blood vessels and their branches to become stiff. Such substances also increase norepinephrine, catecholamine, fibrinogen, platelet aggregation and the number of lipids that cause the blood pressure to rise.

This study revealed that handgrip relaxation produced an impulse sent through the nonnociceptive afferent nerve fibers. These nonnociceptor nerve fibers will close the gate in the thalamus so then the stimulus to the cerebral cortex is blocked. As a result, the intensity of the pain can be reduced. The result of the ANOVA test in this study showed that handgrip relaxation is effective at reducing blood pressure. Handgrip relaxation was most effective at reducing blood pressure on day 3 . The mean difference test between the pre- and posttests indicated that there was a significant decrease in diastolic blood pressure. Thus, it can be concluded that the intervention of handgrip relaxation caused a decrease in blood pressure.

It has been stated that relaxation techniques effectively reduce heart rate, blood pressure and muscle tension, improve well-being and reduce symptom pressure in individuals who experience various situations (Triyanto \& Iskandar, 2012). According to the theory, handgrip relaxation is able to free the locked energies called safety energy so then the energy can flow smoothly (Hill, 2011).
Handgrip relaxation is an easy way to manage emotions and develop emotional intelligence. This technique helps the body, mind and soul to achieve a relaxed state. This relaxation technique is also an action to free the mind and body from tension and stress to increase tolerance to pain. Various relaxation methods are used to reduce anxiety and muscle tension, which results in a decreased heart rate, decreased blood pressure, decreased respiration and decreased muscle tension. This relaxation can be learned easily by any individual to help them achieve regular and relaxed breathing and to release endorphins in the body under normal circumstances.

Based on the results in this study, it could be concluded that handgrip relaxation is able to reduce high blood pressure and headaches in people with hypertension. The results also showed a difference in the decrease in blood pressure and headaches in the intervention group on days 4 and 3 when the intervention was administered.

\section{CONCLUSION}

Handgrip relaxation had an effect on the decrease of systolic and diastolic blood pressure in patients with hypertension. Handgrip relaxation that was given for fifteen minutes over three days can be recommended as a nursing intervention to decrease the blood pressure in hypertensive patients.

\section{REFERENCES}

Carlson, D. J., Inder, J., Palanisamy, S. K. A., McFarlane, J. R., Dieberg, G., \& Smart, N. A. (2016). The efficacy of isometric resistance training utilizing handgrip exercise for blood pressure management: A randomized trial. Medicine (United States), 95(52). https://doi.org/10.1097/MD.000000000000579 1

Ferguson, C. L. (1982). Effects of education and relaxation training with essential hypertension patients.

Hill, R. Y. (2011). Nursing from the inside-out: Living and nursing from the highest point of your consciousness. London: Jones and Barlett Publishers.

Kaplan, N. M. (2002). Kaplan's Clinical Hypertension (8th ed.). Philadelphia: Lippincott Williams \& Wilkins.

Kementerian Kesehatan Republik Indonesia. (2014). Situasi Kesehatan Jantung.

Klabunde. (2015). Konsep Fisiologi Kardivaskular. Jakarta: EGC.

Kozier, B., Erb, G., B. (1997). Profesional Nursing Practice: concept and perspective. California: Addison Wesley Longman, Inc.

Liana, E. (2008). Teknik Relaksasi : Genggam Jari untuk Keseimbangan Emosi.

Mortimer, J., \& McKune, A. J. (2011). Effect of shortterm isometric handgrip training on blood pressure in middle-aged females. Cardiovascular Journal of Africa, 22(5), 257-260. https://doi.org/10.5830/CVJA-2010-090 
Muhadi. (2016). JNC 8 : Evidence-based Guideline Penanganan Pasien Hipertensi Dewasa. Cermin Dunia Kedokteran, 43(1), 54-59.

Nursalam. (2016). Metodologi Penelitian Ilmu Keperawatan (4th ed.). Jakarta: Salemba Medika.

Pinandita, I., Purwanti, E., \& Utoyo, B. (2012). Pengaruh Teknik Relaksasi Genggam Jari Terhadap Penurunan Intensitas Nyeri Pada Pasien Post Operasi Laparatomi. Jurnal Ilmiah Kesehatan Keperawatan, Volume 8, No. 1, Februari 2012 Perk, 8(1), 44-56.

Rekamedik RSUD Dr. M. Haulussy Ambon. (2016). Jumlah Penderita Hipertensi Di RSUD Dr. M. Haulussy Ambon.
Triyanto, E. (2015). Penderita Hipertensi Secara Terpadu. Yogyakarta: Graha Ilmu.

Triyanto, E., \& Iskandar, A. (2012). Pengaruh Aplikasi Health Promotion Model Terhadap Peningkatan Kualitas Kelompok Peduli Hipertensi. Soedirman Journal of Nursing, 7(2), 109-115.

Triyanto, E., Iskandar, A., \& Saryono. (2012). Pengaruh Aplikasi Health Promotion Model terhadap Peningkatan Kualitas Kelompok Peduli Hipertensi. Jurnal Keperawatan Soedirman, 7(2), 109-115.

https://doi.org/10.20884/1.jks.2012.7.2.3634 